\title{
Measuring the Total Economic Value of Traditional Sand Dredging in the Coastal Lagoon Complex of Grand-Nokoué (Benin)
}

\author{
Metogbe B. Djihouessi' ${ }^{1}$, Martin P. Aina ${ }^{1,2}{ }^{*}$, Ben-Vital Kpanou ${ }^{3}$, Nadine Kpondjo ${ }^{1}$ \\ ${ }^{1}$ Laboratoire des Sciences et Techniques de l'Eau, Université d'Abomey Calavi, Abomey-Calavi, Benin \\ ${ }^{2}$ Institut National de l'Eau, Université d'Abomey Calavi, Abomey-Calavi, Benin \\ ${ }^{3}$ Laboratoire d'Economie Rurale et de Gestion des Exploitation Agricoles, Université d’Abomey Calavi, Abomey-Calavi, Benin \\ Email: *marnickson@yahoo.fr
}

How to cite this paper: Djihouessi, M.B., Aina, M.P., Kpanou, B.-V. and Kpondjo, N. (2017) Measuring the Total Economic Value of Traditional Sand Dredging in the Coastal Lagoon Complex of Grand-Nokoué (Benin). Journal of Environmental Protection, 8, 1605-1621.

https://doi.org/10.4236/jep.2017.813099

Received: November 18, 2017

Accepted: December 18, 2017

Published: December 21, 2017

Copyright (ㅇ 2017 by authors and Scientific Research Publishing Inc. This work is licensed under the Creative Commons Attribution International License (CC BY 4.0).

http://creativecommons.org/licenses/by/4.0/

\begin{abstract}
Sand is a crucial resource for society's development. Among the most exploited sand quarries in the world are the lagoon and wetland sand. Although mechanical sand dredging is the most spread technique, manual and traditional techniques are still widely used in West Africa. The purpose of this paper is twofold: to describe traditional sand dredging (TSD), highlighting the procedure used and the structural organization of this activity, and to evaluate the total economic value of TSD in order to help decision making about wetland management. Therefore, TSD occurring in the coastal lagoon complex of Grand Nokoué (CLCGN) in Benin was investigated. Field surveys indicate that TSD is mainly dominated by men, about $93 \%$ of the actors. It required intense physical efforts including diving to the bottom of the lake and removing manually the sand in backed toward the surface of the water. TSD actors are organized in local associations which deliver extraction license and discuss with both the others actors and the local government. The total economic value of the benefits of TSD to the population, estimated using direct market value and replacement cost, was estimated at 2.44 million USD per year for $127,818 \mathrm{~m}^{3}$ of sand extracted. It is clear that introduction of mechanical sand dredging will increase the amount the sand removed and subsequently will increase some benefits such as reduction of flooding amplitude and mitigation of the filling of the lakes. However, mechanical sand removal will also considerably reduce the profit the local population makes from sand commercialization which currently represents $80 \%$ the total economic value of TSD.
\end{abstract}

\section{Keywords}

Traditional Sand Dredging, Ecosystem Service, Coastal Lake, 


\section{Introduction}

The global assessment of the benefits that ecosystems offer to society clearly indicates the great dependence of human well-being on these benefits also known as ecosystem services (ESS) [1] [2] [3]. However, the growth in human population and the growth in per-capita resource consumption have jeopardized the health of many ecosystems around the world [4] [5] [6] [7]. The ESS related to water (ESSw) are among the most threatened because they are found in all ESS categories described by the [1] and therefore are more exposed to anthropogenic interference. In many areas across the globe, human settlements have encroached aquatic and related terrestrial ecosystems including wetlands, marine coastlines, lakes, and mangrove forest, polluting and disturbing theses environments while increasing resource scarcity [4] [8] [9]. Establishing "boundaries" that must not be transgressed could help prevent human activities from causing damage to aquatic ecosystems, but this will also automatically affect societies economies [10]. It is clear today that natural water resource management, particularly ESSw management, involves facing with conflicts between environmental protection and economic development. On approach proposed by researchers to help policymakers across the globe deal with these increasingly complex decisions about natural resource management, it was to collect information on ESS flows in order to estimate their economic values [11] [12].

Economic valuation of ESS has been largely debated in the literature [13] [14] [15], mainly because of the potential importance such values may have in influencing public opinion and policy decisions. In addition, environmental scientists do not agree to the utility and reliability of economic methods for valuing ESS. In order to avoid possible biases (or at least minimise the errors) in the evaluation of ecosystem services, [13] proposed to evaluate them "... from many different conceptual and methodological perspectives at once" with a specified baseline (the nature of the ESS: provisioning, regulating or cultural) and specified measure of change in their ecological states (marginal or non-marginal variation at any physical and temporal scale). Several concepts have been developed to quantify the value of ESS. Some are based on usefulness (instrumental value) through contributions of the ESS to human well-being (utilitarian values); others are based on inherent or intrinsic value and rights (existence value) [16]. Despite a large number of methods and approaches developed for the evaluation of ESS, decision-makers and politicians are still facing challenges in estimating ecosystem values in commensurate terms with opportunity costs. Important elements like data collection, knowledge on the ESS functions or dynamics of ecosystems are usually insufficient for real and total valuation of ESS, especially in developing country where the concept of ESS was still new for decision makers [17] [18] 
[19].

In Benin (West Africa), recognition of the role and importance of ESSw in the population well-being have been increasing, even though very few research studies have been done [20] [21]. In 2014, the government launched the "Plan Delta", a program whose main objective was to propose actions and measures for an Integrated Management of Ouémé Delta. Much information on the services offered by this ecosystem was required to weigh human action on the Ouémé Delta especially on the coastal lagoon complex of Grand Nokoue (CLCGN). The CLCGN (Ramsar site no 1018) consists of two interconnected shallow lakes: Lake Nokoué and Porto Novo Lagoon, three rivers: Ouémé River, So River and Djonou River, one outlet to the Atlantic Ocean: Cotonou Chanel and a deltaic zone know as Delta of Ouémé. It is within this context that the present research aimed to estimate the total economic value of traditional sand dredging (TSD) which is one of the major and oldest ESS benefiting populations after fishery and boat transportation. In this paper, we first analyze the interaction between ESS and the policy context of the CLCGN and show why it is important to economically evaluate TSD. Secondly, we characterize TSD and investigate the relationship between the governance systems and the structuration of TSD users. Thirdly, all the benefits for human well-being have been identified and methods to financially estimate each benefit are developed. Finally, we analyze the interconnectivity between TSD and the other ESS of the CLCGN in the spirit of improving ESS valuation for future project or policy analysis. The research provides the foundation for the inclusion of TSD values in the integrated report of "Plan Delta" management plan.

\subsection{ESS and Policy Context of the CLCGN}

Based on information collected from literature, the ecosystem cascade diagram developed by [22] has been used to link ecological structures and processes of the CLCGN with the direct benefits that the population gets from this ecosystem. The cascade model (Figure 1) indicates that in addition to the conventional ESS directly related to the human well-being provided by coastal wetlands, such as fishery, water purification, transportation, tidal renewal of water quality [23], the

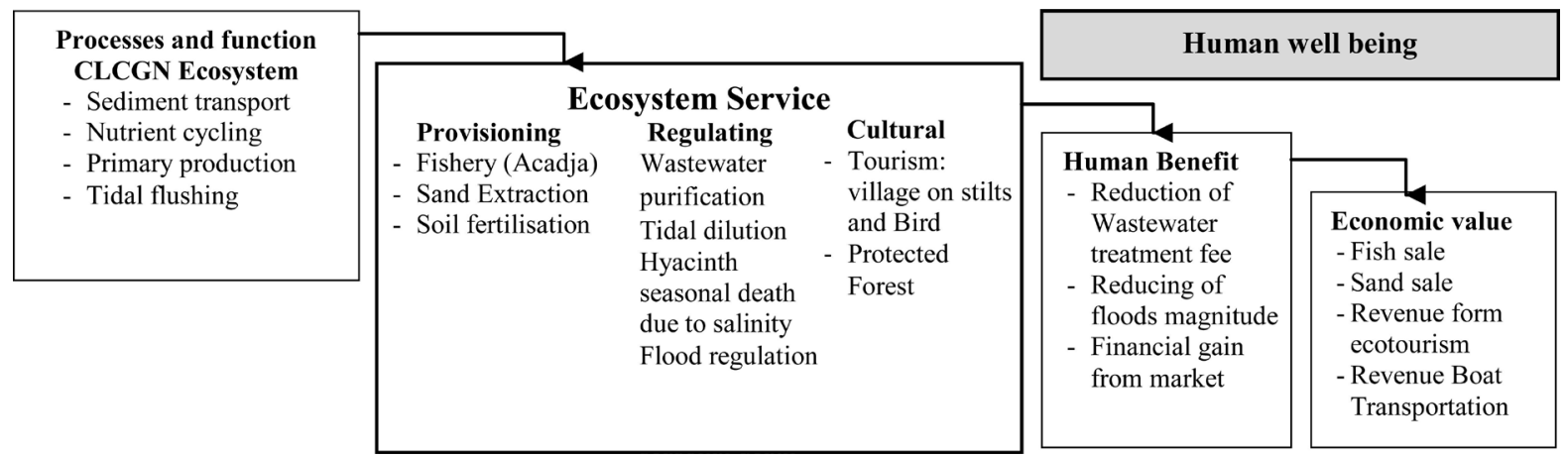

Figure 1. Ecosystem Service Cascade proposed for the CLCGN adapted from [22]. Non-use and intrinsic moral, social, and cultural values are not included. 
CLCGN offers some unusual services including Acadja fishery [24] [25], tourism activity link to the village on stilts [26], seasonal regulation of water hyacinth infestation due to salinity regime [27] and traditional sand dredging TSD. The physical setting of the system is the main characteristic which promotes the observed ESS. For instance, the size of the tributary rivers ensure important sediments supply, the slope in the CLCGN promote sand deposition and the shallow depth of the lakes makes the manual extract of sand (or TSD) possible. The exchange value of the ESS is presented here in Figure 1 as economic value. Most of the goods that the population directly derives from the CLCGN are trade-in market for financial gain.

ESS governance (as defined by [28]) for the CLCGN is regulated by the law on the protection of natural resources in the Republic of Benin, the Ramsar Convention and the Convention on Biological Diversity. The main objectives set by decision makers and which can be also seen as drivers for change were the restoration of aquatic biodiversity and reduction of nutrient load from agriculture, with the main focus on fishery development. One of the restoration measures proposed and which is related to TSD was the increase in the volume of the lake, by sediment removal. The arrangement currently made by decision makers and politicians tend to promote mechanical and industrial dredging and do not include any participation of TSD despite the fact that this activity seems to be well structured with a visible societal importance. Mechanical sand removal, when compared to TSD, will have the advantage to be faster and homogeneous. However, from human benefits (both individual and societal) perspective of this ESS, many questions remain. What will be impacts to CLCGN ecosystem and to human well-being (local population)? How will the other ESS be affected? Relevant to who (stakeholders)? To what extent? All these questions justified the opportunity and need for economic valuation of TSD. The appropriate valuation technique to estimate TSD should add all its economic value, directly and indirectly, related to this ESS.

\subsection{Overview of the Possible Economic Value of TSD}

Based on [1], TSD is categorized as a provisioning service since the dredged sands provide raw materials which are directly traded on the market and used for building constructions. However, given the fact that removal of lagoon sediment helps to reduce sediment accumulation and increases the capacity of the water body to moderate flood events, TSD is also categorized in this research as a regulation service.

Only the anthropogenic values of TSD are considered and the possible intrinsic values of TSD are out of the scope of this study. Thus, based on the literature and on a contextual analysis of the CLCGN, five level of benefit provided by TSD have been identified and presented in Table 1 . Both direct and indirect use of TSD are considered including individual financial profits linked to sand extraction and societal profit such as the improvement of fish habitat, the mitiga- 
tion of flood amplitude and the decreased pressure on terrestrial sand mining. For each type of benefit, an appropriate valuation technique has been identified based on [16] (Table 1). These valuation techniques and the associated data need are described in section 2.2 and in Table 2.

Lagoon sand dredging also present negative environmental impacts. The most recurrent consequence is an increase of the water turbidity which caused the decrease of photosynthetic activity, disturbance of feeding activity of some fish species and the increase of infestation risk for aquatic animals. Another consequence regarding the water quality is the change in the nutrient dynamics of the ecosystems through sediment resuspension. In addition, in many aquatic ecosystems, degradation of aquatic biota and alteration in fish population has been

Table 1. Streamlining Economic Valuation of TSD in the CLCGN.

\begin{tabular}{|c|c|c|c|c|}
\hline \multicolumn{2}{|c|}{$\begin{array}{l}\text { Benefits as good, service or } \\
\text { function }\end{array}$} & Value type & Valuation technique & Data needs \\
\hline 1 & $\begin{array}{l}\text { Profits through sand } \\
\text { commercialization }\end{array}$ & Direct use & Market Price-Based Methods & $\begin{array}{l}\text { Structural organization of the actors } \\
\text { Volume of sand extracted per year } \\
\text { Market price of lagoon sand }\end{array}$ \\
\hline 2 & $\begin{array}{l}\text { Mitigate the filling of } \\
\text { the lakes }\end{array}$ & Indirect use & Benefit transfer: function transfer & $\begin{array}{l}\text { Volume of sand extracted per season and per year. Total } \\
\text { volume of the water body. Total area of the lakes }\end{array}$ \\
\hline 3 & $\begin{array}{l}\text { Deeping some area: } \\
\text { improve pelagic habitat } \\
\text { for fish reproduction }\end{array}$ & Indirect use & Benefit transfer: function transfer & $\begin{array}{l}\text { Volume of sand extracted } \\
\text { Geographic location of extraction points. } \\
\text { Average density of fish in the lakes. }\end{array}$ \\
\hline 4 & Moderate flood events & Indirect use & Benefit transfer: function transfer & $\begin{array}{l}\text { Volume of sand extracted } \\
\text { Area impacted by flooding }\end{array}$ \\
\hline 5 & $\begin{array}{l}\text { Decrease pressure on } \\
\text { terrestrial sand mining }\end{array}$ & Indirect use & $\begin{array}{l}\text { Cost-based Methods: replacement } \\
\text { cost }\end{array}$ & $\begin{array}{l}\text { Volume of sand extracted per year } \\
\text { Market price of sand from other quarries }\end{array}$ \\
\hline
\end{tabular}

Table 2. Data collected for the economic valuation of TSD.

\begin{tabular}{|c|c|c|c|c|}
\hline data & & & & \\
\hline Volume of the water body $\mathrm{m}^{3}$ & \multicolumn{4}{|c|}{ Ouémé River: 9,200,000; L. Nokoué: 250,000,000 ; P. Novo Lagoon: 53,400,000 } \\
\hline $\begin{array}{l}\text { Fish production estimated in } \\
\text { tonnes (based model from [36]) }\end{array}$ & \multicolumn{4}{|c|}{ Ouémé River: 192 tonnes; L. Nokoué: 12,920 tonnes; P. Novo Lagoon: 2380 tonnes } \\
\hline Information on 2010 flood & \multicolumn{4}{|c|}{$\begin{array}{l}\text { Has caused the rise of water between } 25 \text { and } 60 \mathrm{~cm} \text {. More than } 210 \mathrm{~km}^{2} \text { of flooded land. Impact } \\
\text { estimated at } 262 \text { million USD. Flood damage valuation per } \mathrm{m}^{2} \text { was estimated to } 1.21 \mathrm{USD}\end{array}$} \\
\hline \multirow{4}{*}{$\begin{array}{l}\text { Volume of sand extracted in } \mathrm{m}^{3} \\
\text { per year }\end{array}$} & & 2013 & 2015 & 2016 \\
\hline & Ouémé River & 50,695 & 51,074 & 54,074 \\
\hline & P. Novo Lagoon & 43,442 & 42,511 & 43,963 \\
\hline & L. Nokoué & - & 28,576 & 29,781 \\
\hline $\begin{array}{l}\text { Market price of lagoon sand in } \\
\qquad \mathrm{USD} / \mathrm{m}^{3}\end{array}$ & & 15.7 & 16.8 & 17.0 \\
\hline Average price of fish in USD $/ \mathrm{kg}$ & & 2.4 & 2.6 & 3.0 \\
\hline $\begin{array}{c}\text { Market price of land for terrestrial } \\
\text { sand mining USD } / \mathrm{m}^{2}\end{array}$ & & 25 & 25 & 25 \\
\hline
\end{tabular}


linked to sand dredging [29] [30]. However, it is important to note that all these consequences were related to mechanical and industrial sand dredging. Information on possible negative impacts related to manual and traditional sand extraction was not available (or rare) in the literature. Since TSD is very local and needs physical effort, it is supposed that its environmental impacts are minor when compared to mechanical sand dredging and that ecosystem might recover faster from disturbance.

\section{Materials and Methods}

\subsection{Study Site}

The CLCGN is located in the South-eastern of Benin in West Africa (Figure 2). Lake Nokoué $\left(190 \mathrm{~km}^{2}\right)$, the largest water body of the CLCGN is characterized by three major hydrologic periods. A high water period is from September to November, due to important freshwater inputs from the Ouémé River and Sô River as a consequence of heavy rains in North of Benin. This contrasts with a low water period from December to April in which tidal inputs dominate with high salinity concentration in the Lake as long as Cotonou Channel is open to the Atlantic Ocean. Finally, there is slight water from May to August caused by the local heavy rains in southern Benin which supply the Sô and Djonou rivers [31] [32]. Through the channel of Totchè (Figure 2), Lake Nokoué also exchanges freshwater with the Porto Novo lagoon $\left(35 \mathrm{~km}^{2}\right)$ which has only one tributary (Ouémé River) and subsequently two hydrological periods with high water period from September to November. The CLCGN has a mean annual temperature of $30.6^{\circ} \mathrm{C}$ (ranges from $22.4^{\circ} \mathrm{C}$ in August and $33.9^{\circ} \mathrm{C}$ in March) while the mean annual precipitation ranges from $960 \mathrm{~mm}$ to $1340 \mathrm{~mm}$.

Geologically the study area is in the middle of three structures including the

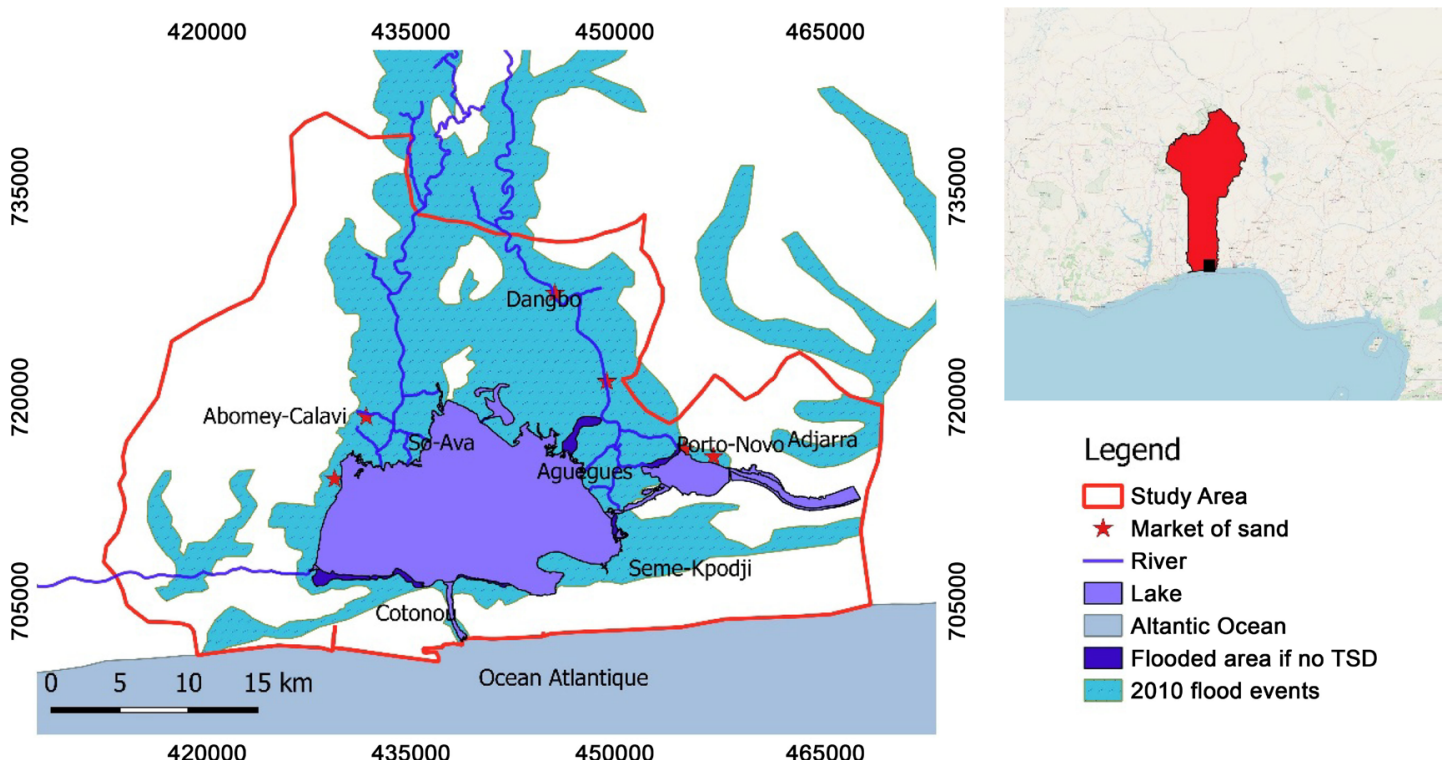

Figure 2. The coastal lagoon complex of Grand Nokoué (CLCGN) including the different sand market, the zone impacted by 2010's flooding event of CLCGN. 
sand barrier in the South, the lower basins of Ouémé and Sô River in the North, and the sub-horizontal plateaux of the Continental Terminal in the East [33]. Topographically the area consists of plain lands with red and yellow sandy soil. Sediments supplies in both Porto Novo Lagoon and Lake Nokoué are mainly controlled by Ouémé River which drains a catchment of approximately 49,300 $\mathrm{km}^{2}$, and the bottom of these water bodies is sandy, sandy-muddy and muddy depending on the location. Ecologically, about 80 fish species have been recorded in CLCGN with a large variety of bird species [34] [35]. The environment of CLCGN is mostly urbanized, embedded in the middle of 9 municipalities and count about 3 millions of peoples. The cities of Cotonou and Abomey-Calavi stand respectively on the south and west shoreline of the Lake and host together more than 2 million habitants. Several fishermen villages have been built on stilts on the Nokoué surface comprising more than 2500 houses. The most important human activities related to the CLCGN are fisheries, boat transportation, ecotourism and traditional sand dredging.

\subsection{Valuation of Traditional Sand Dredging}

The total economic valuation of TSD was made by adding all the benefits provided by this ESS. Table 1 presents each of the identified contribution of TSD to human welfare in CLCGN. In the following, these contributions have been labeled from Benefits 1 to Benefits 5 .

Sand commercialization (Benefit 1): was estimated by Market Price-Based Method. The sand extracted from the lakes were sold and contributed to profits through sand commercialization. The economic value of Benefit 1 was calculated by using the following formula:

$$
\text { Benefit } 1=\text { Volume extracted } * \text { Market price }
$$

Mitigate the filling of the lakes (Benefit 2): was estimated by function transfer which is a Benefit Transfer Method. The function which was transferred here is the use of water as habitat for fish. The idea here was to estimate how much cost a decrease of about one unit length (here $\mathrm{cm}$ ) the water depth in terms of fish population? The approach used considered that the filling of the lakes reduce the available volume of water for fish, and then the fish population. It was assumed the density of the fish population in a lake always adjust to a mean value which is the maximum density for the dominants species. [36] estimated the mean fish density in Lake Nokoué at $0.05 \mathrm{~kg} / \mathrm{m}^{3}$. The economic value of Benefit 2 was calculated by using the following formula:

Benefit 2 = Volume extracted $*$ fish density $*$ price of a unit weight of fish

Deeping some specific area (fish nursery) improve fish reproduction (Benefit 3). The transfer function used for Benefit 2 already considered fish habitat. Therefore a valuation of Benefit 3 was considered as part of Benefit 2. It is important to note that for Benefit 3, the location where sand removal occurs is very important compared to Benefit 2 which considered a homogenous removal across the lake. However, it was challenging to measure how this difference in 
function affects the financial estimation of Benefit 3 when compared to Benefit 2 .

Moderate flood events (Benefit 4): was estimated by function transfer. The flood events of 2010 in Benin resulted in an overflow of $1000 \mathrm{~m}$ of the water bodies in CLCGN. The material damage and the production losses recorded were estimated at 262 million USD. On the basis of these values, the average cost of one square meter of overflow (DPrice) for each lake has been determined. Using QGIS (area and volume calculation plugin), the area which would has been flooded ( Area $_{\text {overflow }}$ ) if there was not TSD was estimated (Figure 2). Flood mitigation benefits provided by TSD in the CLCGN were calculated using the following formula:

$$
\text { Benefit } 4=\text { Area }_{\text {overflow }} * \text { DPrice }
$$

Decrease pressure on terrestrial sand mining (Benefit 5): was estimated by replacement cost. It was assumed that the volume of sand extracted each year from CLCGN could be replaced by terrestrial sand quarries. Terrestrial sand quarries would have requested land cost and road accessibility cost. The cost of sand quarries and road cost associated have been used as the replacement cost of TSD. Based on the volume of lagoon sand extracted, the area of land needed $\left(\right.$ Area $_{\text {needed }}$ ) for terrestrial sand extraction was calculated. The additional transportation cost related to terrestrial sand quarry was calculated based on the distance from the quarries to CLCGN.

$$
\text { Benefit } 5=\text { Area }_{\text {needed }} * \text { price of } 1 \mathrm{~m}^{2} \text { of land }+ \text { Transportation }
$$

The data needed for the valuation of each benefit was listed in Table 1. These data were collected based on two approaches. First, field surveys were conducted to collect primary data. Second, for all the benefits, when supplementary data (which couldn't be provided by the survey) were needed necessary, secondary data were collected.

\subsection{Survey Design and Data Collection}

A Socio-Economic Survey was conducted from November 2016 to April 2017, in order to collect the data to understand TSD and its economic importance in CLCGN. The data collected from this field survey concerned: the ecosystem services description (organization of ecosystem service implementation and actors involved), the identification of actor's characteristics (sex, age, main activity, secondary activities, role in TSD), and the financial revenue from the activity (possible variation in market price, volume extracted, additional cost). An exploratory survey was first organized since almost no literature exists on TSD in CLCGN. It allowed designing survey questionnaire and indicated that $80 \%$ of the activity occurs around Porto Novo Lagoon and Ouémé River against 20\% around Lake Nokoué. After this exploratory survey, snowball sampling method was used to identify the actors to be questioned [37]. It allows building a network of people connected by TSD. In total 135 people were interviewed with $30 \%$ from Lake Nokoué and 70\% from Porto Novo Lagoon. To test the validity 
of the information collected, restitution meetings were organized with three focus groups. Each focus group included a representative of each actor group. A presentation of our understanding of TSD was given to each group. The individuals in the focus groups were asked to point out any elements that were not clear or missing in the presentation. After each focus group, the presentation was improved according to the remarks.

Since all the required information for financial evaluation of TSD could not be collected from field survey, the additional information was collected from published research papers, administrative documents provided by decision makers and municipalities' libraries, and the National Institute for Statistic (secondary data collection). These documents included municipal action plans, study reports financed by the municipalities, the monitoring reports of the TSD activity and soil and occupation maps of the study area.

\section{Results}

\subsection{Characterisation of TSD in the CLCGN}

\subsubsection{Historical Development of TSD}

TSD in the CLCGN covers the entire Porto Novo Lagoon (PNL), the northern part of Lake Nokoué (LN) near the entrance of its tributaries and the long the Ouémé River in the deltaic zone (Figure 2). There is not TSD on Djonou River and the Sô River.

In the early 1960s, the increased need of the population of Porto Novo to build their house in concrete has led to the search for nearby building material. Thus, local communities living nearby PNL (at Djassin Daho; Figure 2), identified a business opportunity and specialized themselves in the extraction and commercialization of lagoon sand. The sand extracted when compared to marine sand (extracted on the coastline of Atlantic Ocean) has the advantage of low salinity and its granulometry allowed it to substitute the gravel in the fabrication of concrete. Therefore, the lagoon's sand started to be exported outside of Porto Novo. From 1980 TSD was spread along the river Ouémé in the lower valley of the Delta but never had the same importance as in Djassin Daho. The activity appeared around 1990 in Lake Nokoué. In contrast to PNL, the reasons for TDS occurrence on Lake Nokoué were not commercial. It was introduced to respond to the need of the populations of Ganvié (villages on stilts) to have portions of land under their houses for breeding. Thus, different textures of sand (from clayey to sandy) were extracted from the nearby flood zones and transported to Ganvié. The populations grouped together in small groups and helped each other in the realization of their breeding grounds.

Following the ban of marine sand extraction on March 4, 2009, by the government of Benin, TSD for the commercial purpose have been amplified. Several markets developed rapidly around the CLCGN. A total of 13 (formal) sand markets were identified by this study in 2017, including 6 markets around the PNL, 3 around Lake Nokoué and 4 along the Ouémé River. Also, two mechani- 
cal sand dredging companies were created around Porto Novo Lagoon, but the functioning and economic valuation of two mechanical sand dredging are out of the scope of this research.

\subsubsection{Description of TSD Procedures}

TSD involves a succession of step with most of the tasks requiring some physical energy. The first step is the preparation of dredging equipment consisting mainly of aluminum buckets, wooden ladders, shovels and motorized boats. Then, the extractor's team explore the lake to identify an extraction site which is the second step. The identification of the site is done intuitively and requires experience from the extractors. An operator embedded a wooden post in the bottom sediment, to identify first the nature of the sediment (since they are looking for sandy sediment), and second whether the depth at the point is safe. Sometimes water hyacinth cover the surface of the water at the identified sites, and it is necessary to clear them to facilitate the inking of the boats. The third step consists of the implementation of the preliminary tasks before the actual sand extraction. This consist of inking the boat by fixing it to 2 to 4 stilts, then the ladder is set up for the descent of the divers to the bottom and their climb to the boat. If necessary, the divers proceed to the removal of the layer of mud and detritus (generally consisting of dead hyacinths) covering the layer of sand to be extracted. The fourth step is the actual sand extraction. The divers pick up the bottom sand using aluminum buckets and climb up to the surface using the wooden ladder. When the boat is considered full, the extraction team proceeds to the regrouping point on the shore (the market). There, women unload the sand from the boat and form the piles on the sand storage platforms. Finally, the sand is loaded into trucks and delivered to customers.

The procedure described above is the same whether the dredging is done in PNL, in LN or in Ouémé River. The procedure has not changed since the establishment of TSD in early 1960. However, some improvements have been done regarding the material used especially the boat which is wider to limit the risks of capsizing once on the water.

\subsubsection{Structural Organization of the ES}

About 1206 persons are the number of people directly involved in TSD. The low representation of women, only $7 \%$, could be explained by the nature of the tasks since the perception of the local society some tasks are exclusively for men (Table 3). However, $89 \%$ of people surveyed, including women, are satisfied with the role women play in the activity. The median age of the actors was 35 years (age ranged from 17 to 70 years) with $75 \%$ under 40 years and $4 \%$ about 60 years. The experience of the actors varies between 1 and 50 years with $5 \%$ of having less than 3 years of experience and 55\% having more than 8 years of experience, meaning $55 \%$ were in the activity before the 2009 government reform. These figures indicate a certain stability in TSD, suggesting an activity already saturated or very difficult to integrate. A spatial analysis of the ethnic origin and 
Table 3. Proportion of each of the groups in the involved in TSD including the perception of the society for each task.

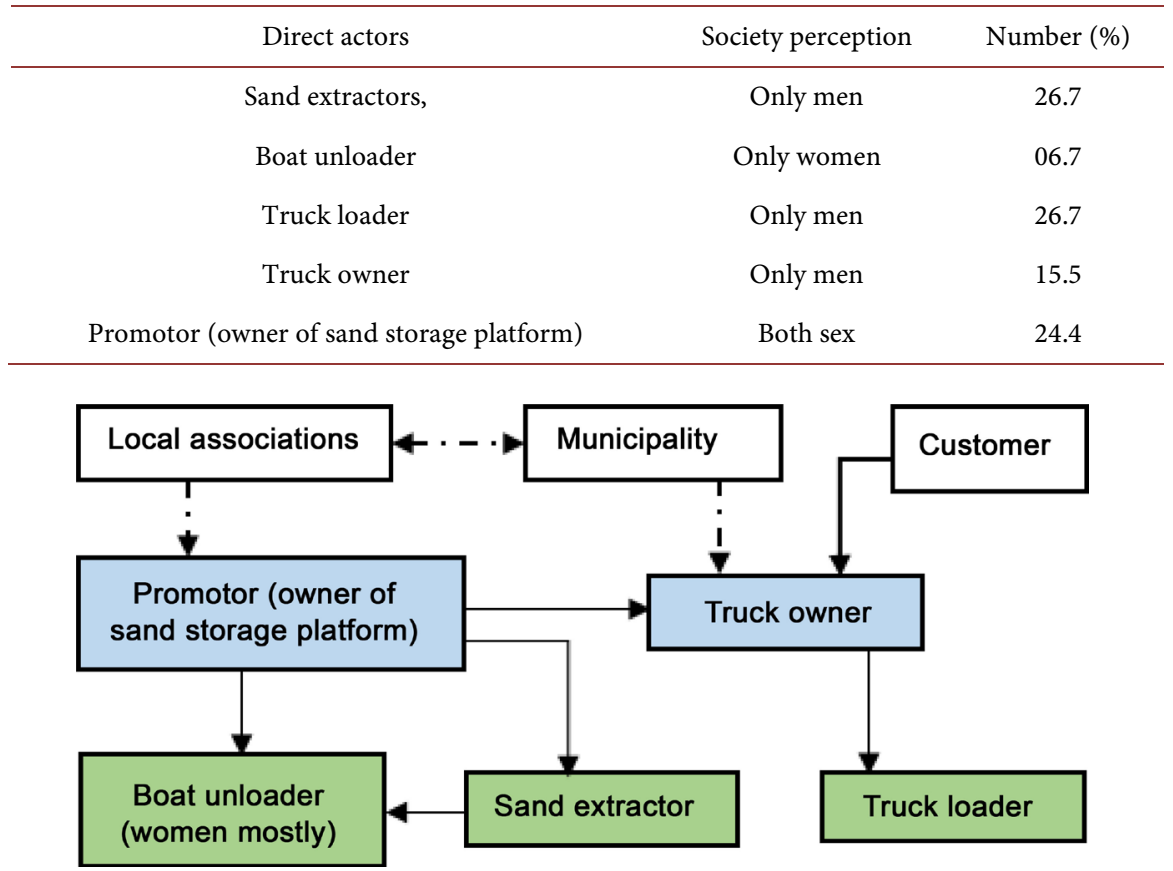

Figure 3. Linkages between the actors involved in TSD. The arrows indicate the direction of employment.

residence places of the actors indicates that $73 \%$ are the indigenous living in the local community and whose families are the predecessors of TSD. They are present in all the groups of actors and have the monopoly of the activity.

Figure 3 presents the connexion between the actors, directly and indirectly, involved in TSD. The overall coordination of the activity is ensured by the owners of the sand storage platforms. They are the ones with the extraction license, issued by the association of extractors or local association. They are also the owner of the boat, ensure the provision of all required equipment to the sand extraction and sell the sand to the truck's owners. They are considered as the promotors of TSD and represents $24.4 \%$ of the direct actors. Another group of actors is the extractors (26.7\%) made up of divers and boatmen. These are the architects of the sand extraction. They choose extraction sites on the lake, determine the periods for diving, the limitations for loading and are responsible in case of the capsizing of the boat. Divers and boatmen have a contract with the promoters and are paid according to the volume of sand extracted. The unloading of sand from boats is ensured by the women. They group the sand in piles according to the color and the size of sand grains. Women are paid by the promoter, which refers to the volume of sand unloaded. The last two groups of actors are the young men who load the sand in the trucks (26.7\%) and the truck's owners (15.5\%). Sand loading (into the trucks) costs and transportation fee to the final destination are directly paid by the clients. The activity is legally regulated by the different municipalities which intervene in the management of con- 
flicts between TSD and the other users of CLCGN (riparian populations, fishermen, boatmen, etc.). They also levy taxes on the activity, in particular on each truck and at from the local associations (Figure 3).

Surveys revealed that $62 \%$ of the extraction sites identified in the CLCGN are privately owned. In other words, the families which are in the activity since its creation, have divided the surface of the water bodies on the basis of seniority and heritage, bringing a concept of private ownership on a public resource. This ownership concept about TSD is very similar to the one observed in Lake Nokoue about acadja fisheries [25]. The phenomenon covers nearly $78 \%$ of the surface area of the PNL, 90\% of the extraction sites in Ouémé River and 12\% of the extraction sites in LN. There may also be sales or sessions of extraction sites to new "owners". The extraction of sand on a "private site" requires an authorization of the "owner" which may be subject to the payment of a right of extraction fixed by the "owner". The appreciation of this mode of functioning varies according to the groups of actors. The promoters who are in fact "owners" believe that this ensures the sustainability of the resource (which might be overexploited) and the security of the activity. The younger, generally the divers and boatmen consider this mode as an abuse of right that should be regulated by the municipal authorities.

\subsection{Economic Value of the ES}

The volume of sand extracted was the major information needed in the economic valuation of TSD. It was calculated from the number of trucks delivered to customers and the volume of the different type of trucks used. It was found that $127,818 \mathrm{~m}^{3}$ of sand are extracted per year with $42 \%$ from Ouémé River, $35 \%$ from Porto Novo Lagoon and 23\% from Lake Nokoué (Table 3). The volume of sand extracted represented to $0.04 \%$ of the total volume of water in CLCGN. When compared to the average filling rate of in CLCGN which was $2.3 \mathrm{~cm} /$ year, the volume of sand extracted contributed to a reduction of $4.4 \%$ of sediment deposition. It was also found based on the volume of sand extracted that about $0.22 \mathrm{~km}^{2}$ of land are saved from flood each year and about $0.013 \mathrm{~km}^{2}$ of land would have been requested to replace TSD by terrestrial sand mining. The other information used in the economic valuation of TSD is presented in Table 4.

The total value of TSD generated by CLCGN is estimated at per year or 2.44 million USD per year (Table 4). Profits through sand commercialization are the

Table 4. Value of benefices of TSD.

\begin{tabular}{lcc}
\hline & Benefit & Value \\
\hline Benefit 1 & Profits through sand commercialization & $1,950,505$ USD \\
Benefit 2 & Mitigate the filling of the lakes & 17,659 USD \\
Benefit 3 & Deeping some area: improve pelagic habitat for fish reproduction & ------ \\
Benefit 4 & Moderate flood events & 230,903 USD \\
Benefit 5 & Decrease pressure on terrestrial sand mining & 229,084 USD \\
\hline
\end{tabular}


largest contribution (80\%) of TSD followed by flood moderation (10\%), a decrease of the pressure on terrestrial sand mining (9\%), and mitigation of the filling of the lakes (1\%). About $9 \%$ of the profits from sand commercialization go to the municipalities as the tax on TSD. An analysis of the activity from 2013 to 2016 indicated an average yearly increase of $2.9 \%$ on the profits made from sand commercialization. The actors reported that sand extraction is a function of the sand demand on the market. They estimate that they can dredge up to 1.5 times the current demand which will result in an increase of the economic value of TSD.

Introduction of mechanical sand dredging in CLCGN is suspected to considerably increased benefit 2 to 5 since more volume of sand will be extracted. The objectives defined by decision maker for mechanical sand removal suggest an increase of more than 100 times of the benefit 2 to 5 . However, mechanical sand removal is expected to negatively impact the direct profits that population make from TSD. The proposed mitigation plans currently suggest the conversion of TSD actors into mechanical dredging. However, it is recalled that most TSD actors may have difficulties in the operation of machines. In addition, $78 \%$ of the people interviewed rejected the idea of working for a dredging company. They defined TSD as a business inherited from their families and want to legate it to their child in turn. An option that could be developed by decision maker is to reserve some area for traditional dredging. This will require many meeting with TSD actors with currently are not associated with the discussion and the introduction of mechanical sand dredging. It is also important to note that mechanical dredging will have a higher environmental impact on both water quality and biodiversity of CLCGN. More research should be done on the environmental impact of TSD, even though from the perspective all the user of CLCGN including fishermen, TSD has a minor effect on the lakes water quality.

\subsection{Linkage between ESS in CLCGN}

TSD is susceptible to influence positively and/or negatively others ESS. Based on the focus groups and on observations from the field the linkage between TSD and the others activities occurring around CLCGN were established (Figure 4).

From the fishermen perspective, sand extraction creates deepwater areas which promote fish reproduction. In Porto Novo Lagoon it clearly appeared that there is a continuous communication between fishermen and sand extractors about where to extract and where to do not extract. More research needs to be done in order to quantify the impact of such arrangement on the real reproduction of fish. Despite this non-institutionalise communication between fishermen and sand extractor, several cases of conflict have been recorded including the destruction of acadja by extractors and installation of new acadja on the space reserved for sand extraction. The concept of ownership on the lake developed by the families of the first users is increasingly being questioned by the new actors, both at the level of the "TSD" and at the level of the acadja fishery. About 75\% of 




Figure 4. Linkage between anthropogenic activities occurring around CLCGN. The connexion between two indicate that there is a relationship which could be mutual benefit and/or conflicts.

the conflicts recorded were between old (more than 10 years in TSD or Fishery) and new (less than 2 years) users. Conflicts management is ensured by municipalities and local associations.

Boat transportation is very dense in CLCGN. The fact that the water complex is in the middle of the most important cities of the countries contribute to the high use of boats for the transportation of people and good. However, transporters and extractors are regularly in conflicts. The field survey revealed that on average one case of extractor's boat capsizing is recorded per day because of the waves generated by transport boats moving very fast. Decision makers tried to impose a speed regulation of some part of the boat traffic but this measure didn't work. Boat transporters accused extractors to overload their boats and then to be more vulnerable to water waves. Usually, financial compensation is required in case of boat capsizing but TSD actors reported this compensation does not cover their losses. There is no apparent relationship between TSD, tourism, vegetal production and breeding activities.

\section{Conclusions}

The economic value of TSD in CLCGN is about 2.44 million USD per year. Even though this activity is traditional, many advantages are derived from it including substantial incomes for the population, mitigation to a certain extent of lake's filling by sediment and slight reduction of flood event amplitude. In addition, field investigation indicated a possible benefit of TSD for the fishery as most of the fishermen believe that sand removal to very particular locations in CLCGN enhances fish reproduction. Further studies should investigate the environmental impacts of TSD which could help decision makers to manage the balance between mechanical and traditional sand dredging. In addition to the value TSD determined in this research, a complete economic valuation of all the ESS in 
CLCGN should include the interaction between TSD, fishery, and transportation. An interesting concept of ownership on lake's services has occurred in CLCGN and needs to be investigated for a suitable management of the resources.

\section{Acknowledgements}

The authors gratefully acknowledge the International Foundation for Science (IFS), Stockholm, for supporting the present work under the IFS Grant W/5840-1.

\section{Conflict of Interest}

The authors declare that there is no conflict of interest regarding the publication of this paper.

\section{References}

[1] MEA (Millennium Ecosystem Assessment) (2005) Ecosystems and Human Wellbeing: A Framework for Assessment. Island Press, Washington DC.

[2] TEEB (The Economics of Ecosystems and Biodiversity) (2011) TEEB Manual for Cities-Ecosystem Services in Urban Management. http://www.teebweb.org/

[3] Watson, R., Albon, S., Aspinall, R., Austen, M., Bardgett, B., Bateman, I., Berry, P., Bird, W., Bradbury, R., Brown, C. and Bulloch, J. (2011) UK National Ecosystem Assessment: Technical Report. United Nations Environment Programme World Conservation Monitoring Centre.

[4] Pérez-Ruzafa, A., Marcos, C., Pérez-Ruzafa, I.M., Barcala, E., Hegazi, M.I. and Quispe, J. (2007) Detecting Changes Resulting from Human Pressure in a Naturally Quick-Changing and Heterogeneous Environment: Spatial and Temporal Scales of Variability in Coastal Lagoons. Estuarine, Coastal and Shelf Science, 75, 175-188. https://doi.org/10.1016/j.ecss.2007.04.030

[5] Rapport, D.J., Costanza, R. and McMichael, A.J. (1998) Assessing Ecosystem Health. Trends in Ecology \& Evolution, 13, 397-402. https://doi.org/10.1016/S0169-5347(98)01449-9

[6] Karydis, M. and University of the Aegean, Lesvos I. (Greece). Department of Environmental Studies; University of the Aegean, Lesvos I. (Greece). Department of Environmental Studies. (2009) December. Eutrophication Assessment of Coastal Waters Based on Indicators: A Literature Review. In Proceedings of the International Conference on Environmental Science and Technology, Vol. 1, University of the Aegean, Chania, Greece.

[7] Richardson, L., Loomis, J., Kroeger, T. and Casey, F. (2015) The Role of Benefit Transfer in Ecosystem Service Valuation. Ecological Economics, 115, 51-58. https://doi.org/10.1016/j.ecolecon.2014.02.018

[8] Ehrlich, P.R. and Ehrlich, A.H. (1972) Population, Resources, Environment: Issues in Human Ecology (No. 301.3 E47 1972). WH Freeman, San Francisco.

[9] Syvitski, J.P., Kettner, A.J., Overeem, I., Hutton, E.W., Hannon, M.T., Brakenridge, G.R., Day, J., Vörösmarty, C., Saito, Y., Giosan, L. and Nicholls, R.J. (2009) Sinking Deltas due to Human Activities. Nature Geoscience, 2, 681. https://doi.org/10.1038/ngeo629

[10] Rockström, J., Steffen, W., Noone, K., Persson, Å., Chapin, F.S., Lambin, E.F., Lenton, T.M., Scheffer, M., Folke, C., Schellnhuber, H.J. and Nykvist, B. (2009) A Safe 
Operating Space for Humanity. Nature, 461, 472-475.

[11] Loomis, J., Kent, P., Strange, L., Fausch, K. and Covich, A. (2000) Measuring the Total Economic Value of Restoring Ecosystem Services in an Impaired River Basin: Results from a Contingent Valuation Survey. Ecological Economics, 33, 103-117. https://doi.org/10.1016/S0921-8009(99)00131-7

[12] Perez-Verdin, G., Sanjurjo-Rivera, E., Galicia, L., Hernandez-Diaz, J.C., Hernandez-Trejo, V. and Marquez-Linares, M.A. (2016) Economic Valuation of Ecosystem Services in Mexico: Current Status and Trends. Ecosystem Services, 21, 6-19. https://doi.org/10.1016/j.ecoser.2016.07.003

[13] Costanza, R., d'Arge, R., De Groot, R., Farber, S., Grasso, M., Hannon, B., Limburg, K., Naeem, S., O’Neill, R.V., Paruelo, J. and Raskin, R.G. (1998) The Value of Ecosystem Services: Putting the Issues in Perspective. Ecological Economics, 25, 67-72. https://doi.org/10.1016/S0921-8009(98)00019-6

[14] Daily, G. Ed. (1997) Nature's Services: Societal Dependence on Natural Ecosystems. Island Press, Washington DC.

[15] Toman, M. (1998) Special Section: Forum on Valuation of Ecosystem Services: Why Not to Calculate the Value of the World's Ecosystem Services and Natural Capital. Ecological Economics, 25, 57-60. https://doi.org/10.1016/S0921-8009(98)00017-2

[16] NRC (National Research Council) (2005) Valuing Ecosystem Services: Toward Better Environmental Decision-Making. National Academies Press.

[17] Keeler, B.L., Polasky, S., Brauman, K.A., Johnson, K.A., Finlay, J.C., O’Neill, A., Kovacs, K. and Dalzell, B. (2012) Linking Water Quality and Well-Being for Improved Assessment and Valuation of Ecosystem Services. Proceedings of the National Academy of Sciences, 109, 18619-18624. https://doi.org/10.1073/pnas.1215991109

[18] Böck, K., Muhar, S., Muhar, A. and Polt, R. (2015) The Ecosystem Services Concept: Gaps between Science and Practice in River Landscape Management. GAIA-Ecological Perspectives for Science and Society, 24, 32-40. https://doi.org/10.14512/gaia.24.1.8

[19] Hackbart, V.C., de Lima, G.T. and dos Santos, R.F. (2017) Theory and Practice of Water Ecosystem Services Valuation: Where Are We Going? Ecosystem Services, 23, 218-227. https://doi.org/10.1016/j.ecoser.2016.12.010

[20] Baba, C.A.K., Osunmadewa, B.A., Mohammed, M.R.A., Aralova, D., Hassan, T. and Csaplovics, E. (2015) Assessing Ecosystem Services for the Integrated Management of Sakabansi Dam in Northern Benin. Conference on International Research on Food Security, Berlin, 1-4.

[21] Kpéra, G.N., Mensah, G.A., Aarts, N. and van der Zijpp, A.J. (2016) Water Quality as an Indicator of the Health Status of Agro-Pastoral Dams' Ecosystems in Benin: An Ecosystem Services Study. Aquatic Ecosystem Health \& Management, 19, 441-451. https://doi.org/10.1080/14634988.2016.1257896

[22] Haines-Young, R. and Potschin, M. (2010) The Links between Biodiversity, Ecosystem Services and Human Well-Being. In: Ecosystem Ecology: A New Synthesis, 110-139. https://doi.org/10.1017/CBO9780511750458.007

[23] Sierszen, M.E., Morrice, J.A., Trebitz, A.S. and Hoffman, J.C. (2012) A Review of Selected Ecosystem Services Provided by Coastal Wetlands of the Laurentian Great Lakes. Aquatic Ecosystem Health \& Management, 15, 92-106. https://doi.org/10.1080/14634988.2011.624970

[24] Welcomme, R.L. (2002) An Evaluation of Tropical Brush and Vegetation Park Fi- 
sheries. Fisheries Management and Ecology, 9, 175-188. https://doi.org/10.1046/j.1365-2400.2002.00292.x

[25] Niyonkuru, C. and Lalèyè, P.A. (2010) Impact of Acadja Fisheries on Fish Assemblages in Lake Nokoué, Benin, West Africa. Knowledge and Management of Aquatic Ecosystems, No. 399, 5.

[26] Sarswat, G. and Kamal, M.A. (2014) A Critical Appraisal of Off-Land Structures: A Futuristic Perspective. Civil Engineering and Architecture, 2, 323-329.

[27] Mama, D., Deluchat, V., Bowen, J., Chouti, W., Yao, B., Gnon, B. and Baudu, M. (2011) Caractérisation d'un Système Lagunaire en Zone Tropicale: Cas du lac Nokoué (Bénin). European Journal of Scientific Research, 56, 516-528.

[28] Lemos, M.C. and Agrawal, A. (2006) Environmental Governance. Annual Review of Environment and Resources, 31, 297-325. https://doi.org/10.1146/annurev.energy.31.042605.135621

[29] Smith, K.G., Diop, M.D., Niane, M. and Darwall, W.R.T. (2009) The Status and Distribution of Freshwater Biodiversity in Western Africa Gland. IUCN, Cambridge, 94 .

[30] Gavriletea, M.D. (2017) Environmental Impacts of Sand Exploitation. Analysis of Sand Market. Sustainability, 9, 1118. https://doi.org/10.3390/su9071118

[31] Le Barbé, L., Alé, G., Millet, B., Texier, H., Borel, Y. and Gualde, R. (1993) Les ressources en eaux superficielles de la République du Bénin. ORSTOM, Paris, 540 p.

[32] Gnohossou, P. (2006) La faune benthique d'une lagune ouest africaine (le lac nokoue au benin), diversite, abondance, variations temporelles et spatiales, place dans la chaine trophique. Thèse de doctorat, Institut National Polytechnique de Toulouse, Toulouse.

[33] Gadel, F. and Texier, H. (1986) Distribution and Nature of Organic Matter in Recent Sediments of Lake Nokoué, Benin (West Africa). Estuarine, Coastal and Shelf Science, 22, 767-784. https://doi.org/10.1016/0272-7714(86)90098-3

[34] Lalèyè, P., Niyonkuru, C., Moreau, J. and Teugels, G.G. (2003) Spatial and Seasonal Distribution of the Ichthyofauna of Lake Nokoué, Bénin, West Africa. African Journal of Aquatic Science, 28, 151-161. https://doi.org/10.2989/16085910309503779

[35] Laudelout, A. and Libois, R. (2003) On the Feeding Ecology of the Pied Kingfisher, Ceryle rudis at Lake Nokoué, Benin. Is There Competition with Fishermen. In: Interactions between Fish and Birds. Implications for Management, 165-177.

[36] Villanueva, M.C., Lalèyè, P., Albaret, J.J., Lae, R., de Morais, L.T. and Moreau, J. (2006) Comparative Analysis of Trophic Structure and Interactions of Two Tropical Lagoons. Ecological Modelling, 197, 461-477. https://doi.org/10.1016/j.ecolmodel.2006.03.016

[37] Atkinson, R. and Flint, J. (2001) Accessing Hidden and Hard-to-Reach Populations: Snowball Research Strategies. Social Research Update, 33, 1-4. 